\title{
Lecturers' and Students' Perceptions and Preferences about ESL Corrective Feedback in Namibia: Towards an Intervention Model
}

\author{
Saara S. Mungungu-Shipale ${ }^{1} \&$ Jairos Kangira ${ }^{1, *}$ \\ ${ }^{1}$ Department of Language and Literature Studies, University of Namibia, Windhoek, Namibia \\ *Correspondence: Department of Language and Literature Studies, University of Namibia, Windhoek, Namibia. \\ E-mail: jkangira@unam.na
}

Received: January 4, 2017

Accepted: January 19, 2017 Online Published: February 26, 2017

doi:10.5430/wjel.v7n1p11

URL: http://dx.doi.org/10.5430/wjel.v7n1p11

\begin{abstract}
This study investigated tertiary lecturers' and students' perceptions and preferences on the provision of Corrective Feedback (CF) in the English as a Second Language (ESL) classroom at the Namibia University of Science and Technology. The study focused on students' speaking and writing skills in the Language in Practice English course. The findings revealed that both lecturers and students perceive $\mathrm{CF}$ as an essential aspect of developing ESL productive skills. Both lecturers and students were of the perception that CF is more focused on English grammar than form. Students preferred more correction than their lecturers provided. Both lecturers and students concurred that metalinguistic feedback is the best practice for CF in English. The contribution this study made is the ten-stage Intervention Model that works towards the effectiveness of ESL CF at tertiary level in Namibia. The model recommends that lecturers should carefully scrutinise the specific ESL target language features; practise a variety of suitable CF techniques; and cater for individual students' specific needs and preferences in learning English as a Second Language at tertiary level.
\end{abstract}

Keywords: corrective feedback; perceptions; preferences; intervention model

\section{Significance of the study}

Error correction and provision of feedback are important aspects of L2 teaching and learning, because making errors is actually inevitable in the language learning process. The major focus of this paper is to present the ten-stage Intervention Model that is proposed for the effectiveness of English as a Second Language (henceforth ESL) Corrective Feedback (henceforth CF). The purpose of the study was to seek answers to the following research questions: 1) How do ESL lecturers and students perceive CF at tertiary level? 2) How do ESL tertiary level students respond to the CF provided to their errors? 3) What do ESL lecturers and students prefer as far as error treatment practice is concerned and why? 4) How can ESL students' errors be treated to promote the correct use of the English language? It is therefore imperative to first look at how the findings respond to these research questions before the presentation of the Intervention Model.

\section{Findings of the Study}

The findings revealed that CF for both speaking and writing skills is perceived by both lecturers and students as an essential aspect of developing ESL productive skills. Generally reporting, half the number of ESL lecturer participants in the present study reported to be confident with how they deal with their students' errors, while the other half showed that they sometimes hesitate and experience trouble with correcting errors of their students. Otherwise, the results illustrated that, overall, CF for both spoken and written errors takes place one way or another, in the ESL class. 


\section{Lecturers' and Students' Perceptions about ESL CF at a Tertiary Level}

\subsection{Findings about Spoken Errors}

Despite the fact that both the lecturer and student participants agree with the fact that students' spoken errors are corrected in the ESL class, a mismatch was found between students' and lecturers' perceptions regarding lecturers' CF practice. A vast majority of students indicated that whenever a student makes an error when speaking in class, a lecturer's typical reactions are corrections. On the contrary, the lecturers' felt that immediate CF is provided at a minimal rate.

Findings about who corrects errors the most, reveal that students feel lecturers are the most likely agents of providing CF in class; otherwise, students self-correct, and if they cannot correct themselves, other students correct them. On the contrary, lecturers are of the view that correction is mostly done either by the same student or by other students in class. A majority of lecturers indicated that the lecturer's CF is the least common in the ESL class. The survey results further show that lecturers sometimes avoid providing immediate $\mathrm{CF}$ to prevent offending students and disrupting their train of thought, otherwise they correct explicitly. A majority of lecturers indicated that they usually correct after the student has stopped talking, at the end of the activity, otherwise they do correction at another planned time.

The findings further indicate that both types of respondents believe that CF should be done collaboratively by lecturers, the student who made an error and peers. However, the findings show a gap in the lecturers' and students' preferences about the main agent of correction. Students believe they learn English better when their errors are corrected by the lecturer, whereas, lecturers suggest that students should self-correct. According to these results, none of the respondents was ready to take CF responsibility.

During speaking activities in class, a majority of lecturers correct errors that affect the message rather than grammar errors or any other type of error. Student respondents specified the three most frequently corrected errors, wrong tense used, wrong verb form and wrong word used; and lecturers identified the most frequent corrected error type as wrong or irrelevant answer, wrong verb form, concord (subject-verb-agreement). Students indicated three least frequent corrected errors in class as pronunciation, wrong or irrelevant answer, and style and register (acceptability in the given situation), while lecturers identified concord (subject-verb-agreement), wrong word order and style and register (acceptability in the given situation). A discrepancy was, however, noticed in these findings when the two types of respondents expressed quite different perceptions. They only agreed on two types of errors, first that wrong verb form receive the most correction, and second that style and register (acceptability in the given situation) is given the least attention when it comes to CF.

Both types of respondents identified slightly different strategies of $\mathrm{CF}$ as the most frequently practised in class; students identified explicit correction and metalinguistic feedback, whereas lecturers indicated explicit correction and recasts or reformulations. The next two choices of lecturers were metalinguistic feedback and clarification request; while students chose clarification request and repetition respectively. These findings highlight some level of agreement between lecturers' and students' perceptions about CF strategies used in class, with a slight gap regarding repetition and recasts or reformulation. The findings, further, reveal that some lecturers are not always confident with correcting errors of their students. Both the lecturers and students believe that almost all the ESL CF strategies are practised in class but at different rates.

\subsection{Findings about Written Errors}

Both lecturers and students agreed that the common practice for CF on students' written work is underlining errors; however, some lecturers claimed to use correction codes. Lecturers complained that due to time constraints, they only provide $\mathrm{CF}$ without comments.

According to students, the three most corrected errors are wrong tense used, wrong verb form and wrong word used; while lecturers indicated that the most frequent corrected error types are wrong or irrelevant answer, wrong verb form and concord (subject-verb-agreement). On the other hand, students pointed out that the least frequent corrected errors as pronunciation, wrong or irrelevant answer and style and register (acceptability in the given situation). In the lecturers' opinion, the least frequent corrected errors are concord (subject-verb-agreement), wrong word order and style and register (acceptability in the given situation). Overall, both types of respondents only agreed on two types of errors that wrong verb form receives the most correction and style and register (acceptability in the given situation) receives the least correction. 


\section{How Students Respond to the ESL Spoken Errors CF: Lecturers' and Students' Perceptions}

A majority of both lecturers and students agreed that when students make errors in class which are corrected, most of the time they admit the error, think about it, and then continue speaking. Students said that they are not offended by immediate correction and want their errors to be corrected when they make them. Surprisingly, a contradictory finding emerged that even lecturers who were most of the time concerned that they do not correct their students' errors in order not to offend them, also claimed that correction does not frustrate or distract the students' concentration when it is provided instantly, while they speak. Both groups of respondents uniformly agreed that the majority of students are by no means threatened or depressed by CF as it is argued by some scholars and use their argument to oppose the CF practice.

\section{How students respond to the ESL written errors CF: Lecturers' and students' perceptions}

Both lecturers and students highly agreed with the statements that, Lecturers must make a follow up on the feedback they give on students' work and Students must revise their work on their own, paying attention to the feedback provided. Lecturers however expressed a strong sentiment that they do not find time to follow up on the feedback they give to students. Students also explained that they only respond to some of the feedback they receive, when sometimes they make time to go through it. Both lecturers and students agreed that students tend not to revise their work after getting corrections back from their lecturers.

Despite the fact that students wanted their lecturers to revise their work with them, they also emphasised that doing corrections on their own, instead of just depending on the lecturers, would help them not only to understand the concepts better but also not to forget what they learn.

There was a mismatch in the perceptions of students and lecturers when they indicated whether students understand the correction codes their lecturers use when marking their work. Lecturers had an impression that their students understand the marking codes and that students are able to respond easily to the feedback given to them. On the contrary, students said that they do not understand all the codes that their lecturers use when marking their work.

The findings concluded that students devote little time to studying English, and as a result they gain little from the CF they receive. Hence, they keep repeating the same errors over and over, regardless of how often they are corrected.

\section{Findings about ESL Speaking Error Correction: Lecturers' and Students' Preferences}

When it comes to the question who should treat errors, both lecturers and students agreed that errors should be mostly treated by the lecturer, and then peers or the student-self who made an error. However, some students seem to have low self-confidence to correct their own errors, and their opinion was for the lecturer to correct their errors. However, the lecturers' opinion is that students learn language the best if they are able to self-correct. So, they suggest that a student who made an error should, at least, first self-correct before receiving assistance from either the lecturer or other students.

Further, students prefer to receive immediate $\mathrm{CF}$ on their spoken errors from their lecturers in class, while lecturers advocate for delayed CF. Both lecturers and students concur that providing corrections to errors accompanied by comments is the best practice for CF. So, students have high expectations of receiving explicit CF with metalinguistic explanations from their lecturers; nevertheless, lecturers deem explicit CF to be the best practice. A discrepancy between the lecturers and students, however, occurs when lecturers rate pronunciation as the second highest type of error that needs correction, while students rank pronunciation to be the least to receive correction.

Two CF strategies explicit and recasts are the most favoured methods of ESL CF among the students. Lecturers prefer explicit correction, otherwise they opt for recasts. Finally, students prefer to be corrected mostly by their lecturers but they also value peer-correction, otherwise self-correction is their last preference.

\section{Findings about ESL writing Error Correction: Lecturers' and Students' Preferences}

The findings indicate the gap between lecturers' and students' opinion about who should correct written errors in students work. A majority of students who responded to the statement that it was the lecturer's duty to correct all errors partly agreed with the point. On the contrary, a majority of lecturers totally disagreed that it is their duty to correct all errors. Only a few students who partially agreed with the statement, still believed in collaborative participation when they asserted that a lecturer is there to guide the students, but not to do everything for them. Both 
lecturers and students strongly recommended wrong or irrelevant answer to receive the highest attention when it comes to CF. Both respondents also agreed that wrong tense used, wrong verb form, and concord (subject-verb-agreement) should also receive great priority for CF.

Both respondents highly agreed with the following three CF strategies: providing explicit CF in ESL writing is useful because students can improve their writing by noticing the corrections that the lecturer provided; the lecturer should show where the error is and give a clue about how to correct it; and comments with corrections are best. A discrepancy came in when students strongly felt, lecturers should give detailed comments; the length does not matter, while lecturers highly believed in the use of correction codes rather than writing long comments.

\section{A proposed Intervention Model towards the Correct use of the English Language}

This study was a form of complementary research that drew on skill-acquisition theory, not only concentrating on instances such as practice and preferences of $\mathrm{CF}$, but also focusing on the opportunities afforded for consolidating emergent ESL knowledge and skills, and therefore enhancing students' ESL proficiency. As Ranta and Lyster (2007) put it, Skill Acquisition theory critically contributes to CF, specifically in the context of practice that leads students from effortful to more automatic second language use. Advocating for feedback provided as a form of instruction, Hattie and Timperley (2007) argue that "feedback and instruction are intertwined in ways that transform the process into new instruction rather than informing the learner only about correctness" (p. 82). Therefore, the last research question of this study sought to find practical ways of CF that could be employed to promote the correct use of the English language.

\section{Synergic Relationships between this Study and Other Empirical Studies on ESL CF}

The results of other various studies emphasise that CF should be made relevant to the recipient (Lyster \& Ranta, 1997; Fukuda, 2004). The findings urge lecturers to engage in continuous research to enable them to know the status of their students, such as language proficiency level, prior knowledge and special needs.

Findings of other ESL empirical studies recommend the use of a variety of CF strategies such as the implementation of feedforward and sandwich feedback (Lillis, 2003; Boud \& Molloy, 2013). They further recommend that CF practices should be made part of the curriculum and the notion of teaching language across the curriculum should be effectively reinforced. Lecturers and teachers should undergo continuous in-service training in order to be fully equipped with relevant skills that enable them to respond effectively to CF (Spencer, 2007). These skills enable them to maintain adequate student-lecturer information exchanges regarding $\mathrm{CF}$, in order to act effectively upon the $\mathrm{CF}$ and to promote effective language learning.

\section{Stages in the Intervention Model Proposed for ESL CF}

Figure 1 below presents a diagram of a ten-stage Intervention Model that works towards the effectiveness of ESL CF. The content of the model was informed by the findings of this study alongside those of other previous studies that investigated CF (e.g. Prabhu, 1989; Han, 2002; Ellis, 2009; Nicholas, Lightbown \& Spada, 2001; Wieczorek, 1991; Diab, 2005; Brown, 2007, 2009; Lillis, 2003; James, 2008; Chaudron, 1977; Long \& Robinson, 1998; Harmer, 2007; Ur, 1996; Sheen \& Ellis, 2011; Loewen, 2012; Bitchener \& Knoch, 2010; Loewen \& Erlam, 2006; Lyster \& Mori, 2006; Egi, 2010; Sheen, 2010; Ferris \& Hedgecock, 2005; Truscott \& Hsu, 2008; Farrell \& Lim, 2005; Ng \& Farrell, 2003; Schulz, 1996, 2001; Tomková, 2013; Park, 2010; Zaman \& Azad, 2012). The model consists of three main divisions with ten stages. The arrows between the stages suggest that at any stage of the process the lecturer can reflect and consider other points indicated at any other stages of the model that may help him or her to make well-informed decisions. The points below the ten-stage Intervention Model diagram shed some light on what each stage of the model suggests for a lecturer who is in the process of deciding his or her own strategies of providing $\mathrm{CF}$ that enhances learning. 


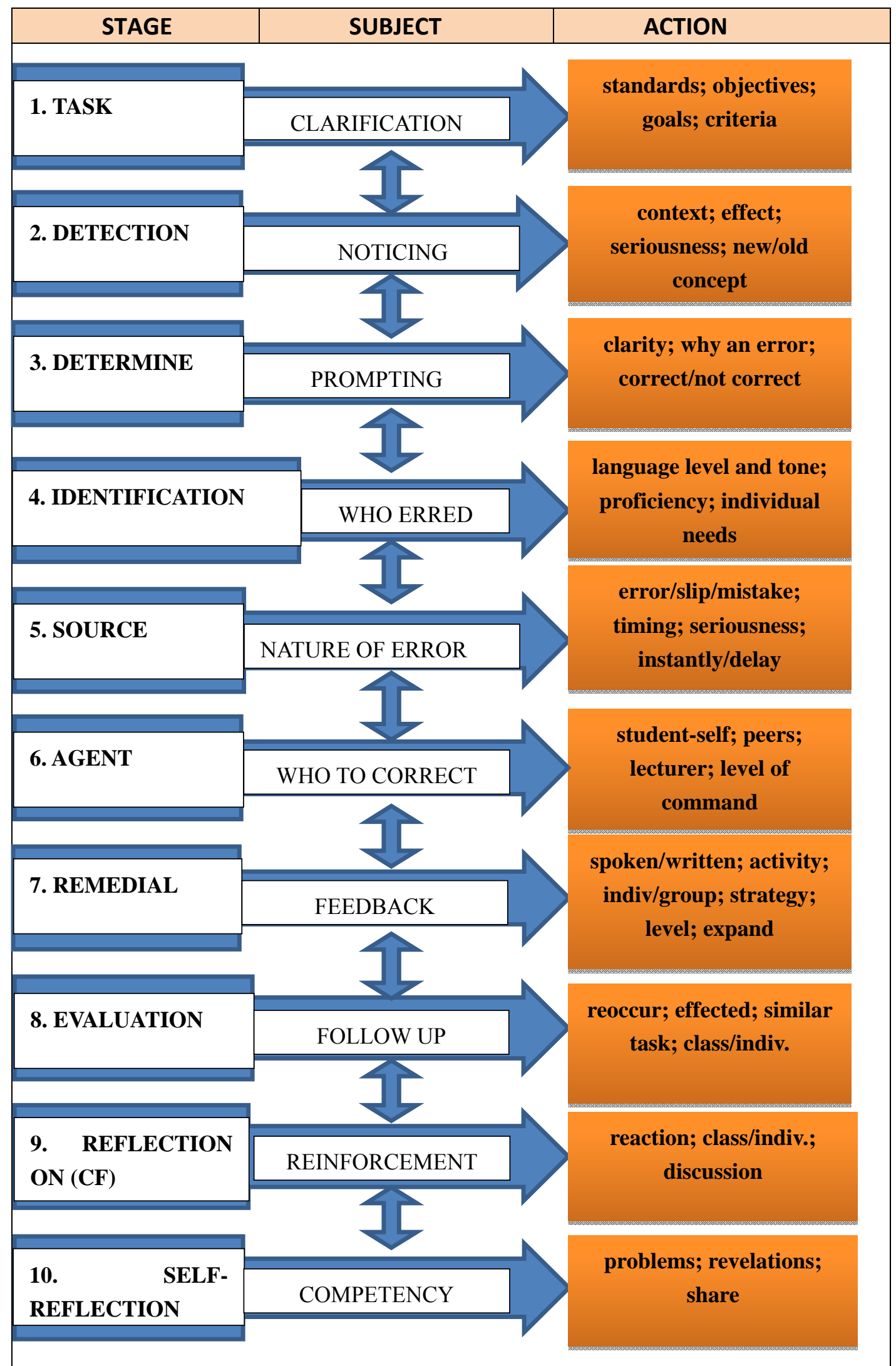

Figure 1. A Ten-Stage Intervention Model towards Effective ESL CF

Source: Own 


\section{Stage 1: TASK}

This is a trigger that initiates performance. Effective CF starts the process and generates the planning stage of the task. CF can be more effective when it is focused on specific linguistic targets than when it does not have a specified language focus. CF strategy should, therefore, be informed by standards; objectives; goals; and criteria directed to the task. Lillis (2003) suggests the "feedforward" strategy of cultivating effective CF. When using the "feedforward" strategy, all the feedback to be given to students should relate to the original assessment criteria.

\section{Stage 2: DETECTION}

$\mathrm{CF}$ is all about guidance and motivation. Feedback should stipulate vivid and unambiguous guidance that is aimed at improving students' performance. Proper guidance can be realised through the concept of noticing. Svalberg (2007) states that noticing embodies cognitive linguistic notions of attention and awareness. To notice the existence of an error requires conscious attention. In order to provide effective $\mathrm{CF}$, a lecturer needs to pay attention consciously and be aware of the circumstance in order to notice the gap between what is produced and what needed to be produced.

\section{Stage 3: DETERMINE}

Find a justification why that error is an error. Decide whether it is worth correcting at this point. Spoken CF can either be given instantly or it can be delayed; otherwise written CF seems to always be delayed. Does the error affect the target language item and objective of the lesson? Students do not appreciate being interrupted while talking, such as when the lecturer tries to point out grammar or pronunciation issues in the student's utterance, which may clarify the theoretical understanding of the concept but less frequently its usage. Correcting every error, pinpointing everything that is wrong and disregarding what is correct can often prevent students from taking risks and participating in the ESL class freely, unless they are precisely sure of what and how they should say something.

\section{Stage 4: IDENTIFICATION}

A lecturer should consider the cognitive and affective needs of the individual student to decide on how to correct; hence, procedures for correcting different students vary. Lyster and Ranta (1997) urge that teachers need to "carefully take into account their students' level of L2 proficiency when making decisions about feedback" (p. 56). CF should indicate what a student has done well, what he or she needs to improve and how he or she can improve. $\mathrm{CF}$ is not about pinpointing errors. A positive comment dilutes resentment involved with erring. The "feedback sandwich" technique enables giving sincere praise regarding a specific area of development together with an indication of where improvement is needed (Boud \& Molloy, 2013).

\section{Stage 5: SOURCE}

Diagnosis of an error type and possible origin should be considered in the process of CF. Whether it is an error, slip or mistake, it should be identified and clearly explained so that students can understand why it is an error. The findings of this study emphasise the need for the provision of comments for improvement and to stipulate what is wrong and how to rectify it.

\section{Stage 6: AGENT}

Situational variables such as classroom atmosphere, type of classmates' behaviour or student-lecturer relationship or background should be considered when deciding on the agent of correction. CF should be decipherable by the intended audience. Different students have different needs and abilities, so feedback should be suitable for both strong and struggling students. A lecturer needs to adapt his or her spoken or written CF strategies for each individual student as per the student's specific needs. Feedback should be expressed in a specific and clear language, free of jargon.

\section{Stage 7: REMEDIAL}

"One size does not fit all" in providing CF. Identify a relevant feedback strategy that suits the circumstance. The effects of feedback depend on the nature of the CF provided. CF should be coupled with some instructional cues such as a variety of possible extra activities that further clarify the concept of the problematic target language feature. Nevertheless, CF should not be too overwhelming in quantity. Students usually view CF as critical and judgemental. Refrain from too negative feedback which is deficient in tone. The findings suggest that direct feedback benefits students to improve accuracy (Ferris 2006; Bitchener, 2008; and Bitchener, Young \& Cameron, 2005), while indirect feedback equips students with long-term improvement that enables them to self-correct because they get more time to ponder on their errors (Ferris, 2006). Findings affirm that students do not only need to receive a mark or grade for their work, but also need a motivation for why they obtained that mark. 


\section{Stage 8: EVALUATION}

Following up on feedback is highly recommended through the findings of empirical studies. Knowing the students' behaviour and considering their reactions towards the CF they received, a lecturer can decide on the follow-up strategy. At this stage, give students a similar task or question to assess their sustained concept gains.

\section{Stage 9: REFLECTION (CF)}

As highlighted in the findings, CF is one of the instructional methods, intended to assist students develop their ESL acquisition. So, it is vital for a lecturer to not only have principles for CF implementation but also to hold discussions about those guiding principles, for instance, why it is necessary to sometimes correct selectively or not correct at all. Some students prefer all their errors to be corrected and may become frustrated or even doubt their lecturer's competence, if their errors are not corrected. Engaging students in discussions about feedback would not only enhance their understanding of the importance of CF but also promote student autonomy. Obviously, some discussion sessions would be necessary on the rationale for CF and when it is appropriate.

\section{Stage 10: SELF-EVALUATION}

A lecturer should have a critical reflection evaluating the whole processes involved in the whole CF process. This stage intends to serve as a platform where a lecturer seeks to understand his or her own strategies and skills of providing feedback, through evaluating and making decisions whether to make adjustments on his or her own CF practices. A lecturer should, for instance, monitor the level of anxiety that was caused by a certain CF strategy and make some adjustments accordingly. This study recommends the on-going development of lecturers or teachers and in-service training to sharpen their teaching skills. If a lecturer discovers any feedback strategy that works successfully towards the learning of ESL, he or she should share his or her discovery with other ESL lecturers.

\section{Discussion}

Providing CF to students' productive tasks should be considered an essential skill and talent that requires high levels of expertise for lecturers to be able to balance and cater for both lecturers' and students' preferences about CF practice, which are at times contradictory. Therefore, the ten-stage Intervention Model recommends three major general practical aspects for $\mathrm{CF}$ at tertiary level. In order to reach a verdict on how CF can be best practised, lecturers should: carefully scrutinise the particular ESL target language feature that is dealt with in class; practise a variety of suitable CF techniques aimed at producing student-generated repairs; and then provide suitable cues that encourage self-repair and cater for individual students' specific needs and preferences. Nonetheless, at times class sizes at tertiary institutions are too huge, which may become a challenge for lecturers to easily implement this Intervention Model. It is therefore recommendable that tertiary institutions consider the distribution of smaller manageable L2 class groups to create an environment conducive for the implementation of the Intervention Model. This Intervention Model should, however, not be regarded as mandatory to lecturers but rather as a series of stages that lecturers can consider when deciding their own CF policies that suit their students circumstances. The model therefore is intended to contribute to the development of ESL lecturers. Hence, in-service training for lecturers may serve as a remedy to handling CF confidently and effectively (Spencer, 2007).

\section{Conclusion}

In the final analysis, the findings of this study show that both the students and lecturers concurred, ESL students' errors should be corrected. The results of the survey, generally, illustrate that the students and lecturers had significantly different perceptions and preferences about ESL CF. Students yearned for more CF than lecturers provided on both spoken and written errors.

Overall, the findings about lecturers' and students' preferences seem to highlight significant discrepancies. These findings should, however, be taken cautiously by ESL lecturers not to cause confusion and generate more discomfort in their practice of providing CF. Even though students desired to receive as much CF as possible and identified their preferences about what errors should be corrected, lecturers should still tap their own experience with CF either as lecturers or even as students at their time. In fact, flexibility and open-mindedness are strong qualities of a good instructor or lecturer. Of course, it is imperative for lecturers to discover their students' perceptions and preferences about CF. Nonetheless, lecturers should be cautious and critically sieve their findings so that ultimately they retain what they deem relevant for their practices. James (1998) suggests that "students' preferences for certain types of correction cannot be ignored of course; nor should they be put on a pedestal, because they are not necessarily more 
effective for being preferred" (p. 253). In essence, even though students' preferences can be underscored, the fact remains, such preferences may not be ideal or more effective than other practices. The final verdict should therefore be left in the individual lecturer's court to determine what is most apposite to his or her particular students' circumstances.

\section{References}

Bitchener, J. (2008). Evidence in support of written corrective feedback. Journal of Second Language Writing, 17, $102-118$.

Bitchener, J., \& Knoch, U. (2010). The contribution of written corrective feedback to language development: A ten month investigation. Applied Linguistics, 31(2), 193-214.

Bitchener, J., Young, S., \& Cameron, D. (2005). The effect of different types of corrective feedback on ESL student writing. Journal of Second Language Writing, 9, 227-258.

Boud, D., \& Molloy, E. (2013). Rethinking models of feedback for learning: the challenge of design. Assessment and Evaluation in Higher Education, 38(6), 698-712. http://dx.doi.org/10.1080/02602938.2012.691462

Brown, A. (2009). Students' and teachers' perceptions of effective foreign language teaching: A comparison of ideals. Modern Language Journal, 93, 46-60.

Brown, H. D. (2007). Teaching by principles. White Plains, NY: Pearson Education.

Chaudron, C. (1977). A description model of discourse in the corrective treatment of learners' errors. Language Learning, 27, 29-46.

Diab, R. L. (2005). Teachers' and students' beliefs about responding to ESL writing: A case study. TESL Canada Journal, 23, 28-43.

Egi, T. (2010). Uptake, modified output, and learner perceptions of recasts: Learner responses as language awareness. The Modern Language Journal, 94, 1-21. http://dx.doi.org/10.1111/j.1540-4781.2009.00980.x

Ellis, R. (2009b). Corrective feedback and teacher development. L2 Journal, 1(1): 3-18.

Farrell, T. C., \& Lim, P. C. P. (2005). Conceptions of grammar teaching: A case study of teachers' beliefs and classroom practices. TESL-EJ, 9(2), 1-13.

Ferris, D. R. (2006). Does error feedback help student writers? New evidence on the short- and long-term effects of written error correction. In K. Hyland and F. Hyland (Eds.), Feedback in second language writing: Contexts and issues (pp. 81-104). Cambridge, UK: Cambridge University Press.

Ferris, D. R., \& Hedgcock, J. (2005). Teaching ESL composition: Purpose, Process, and Practice. Mahwah, NJ: Lawrence Erlbaum.

Han, Z. H. (2002). Rethinking of corrective feedback in communicative language teaching. RELC Journal, 33, 1-33.

Harmer, J. (2007). The Practice of English Language Teaching (4th ed.). London: Longman.

Hattie, J., \& Timperley H. (2007). The power of feedback. Review of Educational Research, 77(1), 81-112.

James, C. (1998). Errors in language learning and use: Exploring error analysis. London: Longman.

James, C. (2008). Errors in Language learning and use: Exploring error analysis. Longman: The University of California.

Lillis, T. (2003). Student Writing as "Academic Literacies": Drawing on Bhaktin to Move from Critique to Design. Language and Education, 17(3), 192-207.

Loewen, S. (2012). Instructed Second Language Acquisition (Ed.). The Encyclopaedia of Applied Linguistics. Blackwell Publishing Ltd. http://dx.doi.org/10.1002/9781405198431.wbeal0545

Loewen, S., \& Erlam, R. (2006). Corrective feedback in the chatroom: An experimental study. Computer Assisted Language Learning, 19, 1-14.

Long, M. H., \& Robinson, P. (1998). Focus on form: Theory, research, and practice. In C. Doughty and J. Williams (Eds.), Focus on form in classroom second language acquisition (pp. 15-41). Cambridge: Cambridge University Press.

Lyster, R., \& Mori, H. (2006). Interactional feedback and instructional counterbalance. Studies in Second Language Acquisition, 28, 269-300. http://dx.doi.org/10+10170S0272263106060128 
Lyster, R., \& Ranta, L. (1997). Corrective feedback and learner uptake: Negotiation of form in communicative classrooms. Studies in Second Language Acquisition, 19, 37-66.

Ng, J., \& Farrell, T. S. C. (2003). Do teachers' beliefs of grammar teaching match their classroom practices? (A Singapore case study.) In D. Deterding, A. Brown and E. L. Low (Eds.), English in Singapore: Research on grammar. (pp. 128-137). Singapore: McGraw Hill.

Nicholas, H., Lightbown, P. M., \& Spada, N. (2001). Recasts as feedback to language learners. Language Learning, $51,719-758$.

Park, H. S. (2010). Teachers' and learners' preferences for error correction. California State University, Sacramento.

Prabhu, N. S. (1989). Three models in second language pedagogy. Journal of English and Foreign Languages, 3, 1-13.

Ranta, L., \& Lyster R. (2007). A cognitive approach to improving immersion students' oral language abilities: The Awareness-Practice-Feedback sequence. In R. De Keyser (ed.), Practice in a second language: Perspectives from applied linguistics and cognitive psychology. Cambridge: Cambridge University Press, (pp.141-160).

Schulz, R. A. (1996). Focus on form in the foreign language classroom: Students' and teachers' views on error correction and the role of grammar. Foreign Language Annals, 29(3), 343-364.

Schulz, R. A. (2001). Cultural differences in student and teacher perceptions concerning the role of grammar teaching and corrective feedback: USA-Colombia. Modern Language Journal, 85(2), 244-58.

Sheen, Y. (2010). Differential effects of oral and written corrective feedback in the ESL classroom. Studies in Second Language Acquisition, 32, 203-234.

Sheen, Y., \& Ellis, R. (2011). Corrective feedback in Language teaching. Handbook of Research in Second Language Teaching and Learning, 2, pp. 593-610. Routledge Taylor \& Francis Group: New York and London.

Spencer, B. (2007). Towards greater equality: Power and role relations involved in response to student writing. Language Matters: Studies in the Languages of Africa, 38(2), 299-315. http://dx.doi.org/10.1080/10228190701794640

Svalberg, A. M-L. (2007). Language awareness and language learning. Language Teaching 40(4), 287-308.

Tomková, G. (2013). Teaching English Language and Literature for Secondary Schools: Error Correction in Spoken Practice. (Master's thesis, Masaryk University.) Retrieved from: http://is.muni.cz/th/261663/ff_m/Tomkova_error_correction_in_spoken_practice.pdf

Truscott, J., \& Hsu, A. Y. (2008). Error correction, revision, and learning. Journal of Second Language Writing, 17, 292-305.

Ur, P. (1996). A Course in Language Teaching. Cambridge: Cambridge University Press.

Wieczorek, J. A. (1991). Error evaluation, interlanguage analysis, and the preterit in the Spanish L2 classroom. The Canadian Modern Language Review, 47(3), 497-511.

Zaman, M., \& Azad, A. B. (January-June 2012). Feedback in EFL Writing at Tertiary Level: Teachers' and Learners' Perceptions. ASA University Review, 6(1), 371-383. 